\title{
Тишкин П.А. \\ Профессионально-прикладная физическая подготовка - одно из важнейших направлений физического воспитания студентов
}

Московский автомобильно-дорожный институт (МАДИ)

(Россия, Москва)

doi:10.18411/lj-31-03-2018-51

idsp: 000001:lj-31-03-2018-51

В здоровом теле - здоровый дух, на самом деле - одно из двух.

д. биол. н., проф. С. В. Савельев

В настоящее время для физических и умственных нагрузок не выработаны достаточно объективные критерии, так как данное разделение весьма условно не только с трансцендентальной точки зрения, но и с физиологической. Центральная нервная система принимает активное участие в любой мышечной деятельности, как орган, регулирующий и координирующий все процессы в организме, а даже «незначительная умственная нагрузка обязательно вызывает статические усилия мышц, так как на подсознательном уровне мозг управляет внутренними процессами для защиты от перегрузок» [1, с.18]. Данные процессы особо активизируются с внедрением инноваций в технологических, управленческих, организационных, институциональных и других социальноэкономических преобразованиях, которые сопровождаются все более возрастающей интегративной деятельностью головного мозга. Вместе с тем роль и значение физических упражнений, физкультурно-спортивной активности для людей различных возрастов, особенно для детей и молодежи, неимоверно возрастает.

Гиподинамия (недостаточность движения) требует культа здоровья, физического совершенства, сочетаемого с активной умственной и интеллектуальной деятельностью, подобно Древней Греции. Так в Спарте, целью физического воспитания, по выражению Платона, «...была подготовка подрастающего поколения, способного побеждать и управлять в любых условиях» [2, с.46], а к этому добавлялось «умственное и эстетическое развитие, по принципу философии aureamediocritas Квинта Горация Флакка» [3, с.51]. Вся система физического воспитания в Древней Греции и все занятия физическими упражнениями имели прикладной характер - готовили к военным действиям, которые постоянно проходили между древнегреческими полисами. Постепенно соревнования по метанию копья, бегу, прыжкам, гонкам на колесницах, фехтованию и борьбе сменялись на жесткую и профессиональную спортивную подготовку в целях достижения максимальных результатов. Начали появляться "звезды" среди наездников и гладиаторов с немыслимыми заработками, повсеместно стали открываться гладиаторские школы, возводиться грандиозные арены для сотен тысяч зрителей. Строились роскошные сооружения - термы, включающие бани, бассейны и спортзалы, в которых римляне занимались фехтованием, упражнениями с гирями, подвижными играми и гимнастикой. На закате Императорского периода, когда появились первые спортивные объединения, фракции и партии, спортивные арены стали также местами политических баталий. К сожалению, «распространение христианской религии привело к упадку физической культуры в Древнем Риме» [6, с.599], место которой в дальнейшем заняла католическая церковь, наложившая запрет на совершенствование тела и направившая все усилия на спасение души.

Устойчивые традиции использования физических упражнений для оздоровления и повышения физической подготовленности населения существовали и на Востоке. По данным написанного на санскрите сборника древне индийских трактатов Аюр - Веда Гараки, «коренное население древней Индии располагало наиболее ценными традициями 
в области ритуальной оздоровительной гимнастики, танца, самообороны без оружия и оздоровительного массажа. Особенности хатха-йоги обозначаются Свами Шиванандой, как направляющие прану (жизненную энергию) внутрь, в отличие от обычных физических упражнений, выводящих ее наружу» [5, с.31].

Бурное развитие промышленности в конце XVIII века также требовало повышенного внимания к физической подготовленности людей, к их физической рекреации, что способствовало возникновению и развитию различных видов спорта, а «громкие археологические раскопки древней Олимпии вызвали повышенный интерес к античной культуре Древней Греции, что способствовало П.Кубертену возродить Олимпийские игры»[4, с.89].

Современная система физического воспитания в вузах, направленная на обучение двигательным действиям, на развитие и совершенствование физических качеств, имеет также прикладной характер в форме приобретения прикладных знаний по использованию средств физкультуры в режиме труда и отдыха, в форме профессионально-прикладной физической подготовки. Профессионально-прикладная физическая подготовка студентов (ППФП) включает теоретические занятия в виде цикла лекций по этому направлению и практические занятия. Главной целью ППФП является воспитание прикладных физических и специальных качеств, умений и навыков, необходимых в избранной профессиональной деятельности. На основе изучения условий и характера труда будущих выпускников разрабатывается профессиограммаспециальности с учетом которой составляется комплекс мер по использования физкультуры и спорта для снижения утомления от данной профессии, повышения производительности труда, комплекс мер по улучшению врабатываемости в начале трудового дня и восстановлению сил после него. При этом должны учитываться индивидуальные особенности личности, психическое здоровье и профессиональные умения каждого. Важно обеспечить сознательное и методически правильное использование средств физкультуры и спорта для обеспечения ЗОЖ и подготовки к возможным инновационным видам труда данной специальности.

В рамках использования ППФП можно проводить соревнования, конкурсы профессионального мастерства на звание «Лучший по профессии». Доцент кафедры изысканий и проектирования железных и автомобильных дорог СГУПС Шевчук С. С. рассказывая о полуфинале Всероссийского чемпионата профессионального мастерства для дорожных организаций Сибирского федерального округа, считает, что «...польза от этого огромная как для участников, так и для экономики в целом» $[8$, с.2]. Будучи главным судьей соревнований по мастерству водителей землеройно-транспортных машин, которые используются для построения дорожного покрытия, С. Шевчук отмечает: «Это на первый взгляд кажется, что здесь вот такие игры, на самом деле это определение степени профессионализма». Говоря о ППФП дорожных специальностей, следует отметить, что для освоения работы с основными строительными инструментами, изучения наиболее оптимальных приемов работы, а также, чтобы почувствовать структуру и наклон дорог и тротуаров, в ППФП может входить комплекс физических упражнений с лопатами, носилками, снегоуборочными скребками и прочим основным инвентарем дорожных рабочих.

В связи с увеличением доли умственного труда в ППФП студентов особое внимание надо уделить развитию статической физкультуры с использованием упражнений йоги. В основе ее технологического алгоритма лежит система физических упражнений, гармонично тренирующих ткани опорно-двигательного аппарата и внутренних органов. В зависимости от профессиональной направленности факультета можно построить общую тренировочную систему и «получить полную и гармоничную компенсацию всех односторонних воздействий на организм»[9, с.11]. Возрастающий объем статических нагрузок требует разработки специализированной физкультуры для профилактики правильного функционирования опорно-двигательного аппарата, постепенно приучая студентов к сохранению статических поз, что положительно влияет 
не только на осанку, но и способствует увеличению объема мышц, наращиванию мышечной силы. Движения станут более точными и согласованными, решится проблема избыточного веса, растяжения и скручивания позвоночного столба. Повысится его гибкость, улучшится процесс питания каждого позвонка, что будет способствовать формированию правильной осанки, компенсировать негативное воздействие неправильных поз, в которых будущий специалист проводит большую часть времени в течение дня и даже во сне. Работа с шейным отделом позвоночника позволит нормализовать питание головного мозга, глаз, поможет улучшить память, способность к сосредоточению, принятию и усвоению новой информации. Укрепление мышц спины и живота даст позвоночнику необходимую надежную поддержку. Расширение грудной клетки, происходящее при практике многих асан, поможет легким раскрыться в полном объеме, нормализует работу органов дыхания и избавит от бронхо-легочных проблем. Как показывает опыт, «практика асанхатха-йоги развивает интеллектуальные способности человека, а также оказывает положительное воздействие на психику»[10, с.7]. Упражнения на расслабление, дыхание и медитацию помогут развить способности к образному мышлению, при этом этическое и эстетическое совершенствование осуществляется естественно. Высокая эффективность адаптированной йоги при систематических занятиях обусловлена, прежде всего, ее способностью восстанавливать защитные системы организма и обмен веществ, нормализовать работу нервной системы и кровообращение. Одним из преимуществ хатха-йоги является то, что она практически исключает травматизм, так как в ней отсутствует соревновательный элемент.

В рамках ППФП в вузе, как правило, используются в большинстве своем «традиционные» виды спорта - футбол, хоккей, баскетбол и т.д. Однако, учитывая высокую компьютеризацию всех профессий в настоящее время, а также практически повсеместную интернет зависимость молодых людей, на наш взгляд целесообразно в вузах вводить образовательные программы и занятия по киберспорту, который официально признан и переведен во второй раздел - «виды спорта, развиваемые на общероссийском уровне» $[11$, c.6]. Пока на сегодняшний день только в одном вузе России осуществлен набор студентов на специализацию киберспорт, в то время как, по разрозненным данным, «в Азии уже существуют специальные учебные заведения для киберспортсменов»[12, с.1].

В заключении следует подчеркнуть, что одной из важных задач ППФП студентов является соблюдать рациональный режим труда и отдыха, позволяющий прийти к достижению поставленной цели за счет разумного сочетания умственных нагрузок при работе за компьютером, физического труда, двигательной активности и оздоровления.

$$
* * *
$$

1. Физическая культура студента. Учебник для студентов вузов./ Под.ред. В.И. Ильинича. М.:Гардарики,1999. - С. 227.

2. История физической культуры и спорта: конспект лекций для высшего профессионального образования / М.А. Соломченко, Т.А. Пеленицина. - Орел: ФГБОУ ВПО «Госуниверситет-УНПК», 2012. $-84 \mathrm{c}$.

3. Кв. Гораций Флакк: Книга Эподов. Предисл., пер. и прим. Г. М. Севера. (Серия «Новые переводы классиков».) Toronto: Aeterna, 2015.

4. Олимпийские мемуары / Пер. с фр. - М.: Рид Групп, 2011. 176 с., Серия «Библиотека РМОУ»

5. Николаева, М.В. Практика Хатха-йоги [Текст] / М.В. Николаева. - Спб.: Азбука-классика, 2007. - 57 с.

6. Иванов М. С., прот. Цыпин В. Ересь // Православная энциклопедия. — 2008. - Т. 18. — С. 598 -607.

7. В. Козлова Министр образования рассказала, сколько школьников погибло на уроках физкультуры РБК №11.2017г.

8. Протокол Полуфинала Всероссийского чемпионата профессионального мастерства «Лучший по профессии» для дорожных организаций Сибирского федерального округа // 2016.

9. Сидерский, А.В. Хатха-йога как технология интегрального тренинга (концептуальный очерк) [Текст] / А.В. Сидерский. - Киев.: Ника-центр, 2011. - 160 с. 8. Ульмасбаева, Е. Йога для начинающих [Текст] / Е.Ульмасбаева.- М.: Эксмо, 2011. - 176 с. 
10. Нетрадиционные формы гимнастики : метод. рекомендации [Текст] / [сост.: Н.А. Дурдаева ]; Саран.кооп. ин-т РУК. - Саранск, 2009. - 28 с.

11. Приказ Минспорта РФ от 16.03.2017 №183 «О признании и включении во Всероссийский реестр видов спорта спортивных дисциплин, видов спорта и внесении изменений».- Всероссийский реестр видов спорта" Зар. в Минюсте России 13.04.2017 N 4635913 апреля 2017 г.

12. Физическое состояние студентов и возможные пути его совершенствования: учебно-методическое пособие для студентов вузов / В.И. Вишневский [и др.]; под ред. В.И. Вишневского. - М.: МАДИ, 2017. $-120 \mathrm{c}$.

13. Щербакова В.Л. Современные модели физкультурно-оздоровительной работы в системе физического воспитания вуза: учебно - методическое пособие - М.:Изд-во "Переспектива",2017. - 82с

14. www.cuder.sport.ua

\section{Финашина T.B. \\ Организация системы военно-патриотического воспитания в условиях городского поселения}

Президентская академия РАНХиГС (Россия, Москва)

doi:10.18411/lj-31-03-2018-52

idsp: 000001:lj-31-03-2018-52

\section{Аннотация}

В статье рассматриваются актуальность, значение, цели, задачи, направления, формы и методы патриотического воспитания российских школьников в условиях городского поселения. Обосновывается педагогическая программа патриотического воспитания.

Ключевые слова: воспитание, патриотизм, патриотическое воспитание школьников, патриотическое воспитание, воинский долг, система ценностей патриотического воспитания

Военно-Патриотическое воспитание представляет собой систематическую многомерную целенаправленную и слаженную деятельность государственных органов, общественных объединений и организаций по воспитанию у молодежи патриотического сознания, чувства верности своему Отечеству, готовности защищать его как основной Конституционный долг при защите национальных интересов Российской Федерации и обеспечении ее безопасности.

В настоящее время значительно возросла острота и востребованность военнопатриотического воспитания как конкретного направления патриотического воспитания.

Во-первых, в результате сложной военно-политической ситуации в мире и вокруг России, появления новых угроз ее национальной безопасности и вероятности возникновения вооруженных конфликтов с ее участием.

Во-вторых, в связи с высоким увеличением роли и важности повышения квалификации для военной службы молодежи до призывного возраста, повышается резкое сокращение ее продолжительности (до одного года).

В-третьих, из-за неудачных и безнадежных попыток найти долгое время альтернативу военно-патриотической ориентации в патриотическом воспитании как основной составляющей новообразованной системы этой деятельности.

Поэтому сегодня высоко повышается роль и значение образовательной организации, реализующей патриотическое и военно-Патриотическое воспитание, тем самым внося заметный вклад в воспитание у молодежи готовности к защите Отечества и военной службы. Этот вклад действительно реален. 